\title{
MONSTROUS WICKEDNESS AND THE JUDGMENT OF KNIGHT
}

\author{
Penny Crofts*
}

In February 2000, Katherine Mary Knight killed, then skinned, decapitated and cooked her lover in rural Australia. Knight pleaded guilty to murder and received a life sentence, against which she unsuccessfully appealed in Knight $v R$ [2006] NSWCCA 292. I consider the way in which the majority judgments organised and expressed Knight's culpability in accordance with a model of monstrous wickedness, arguing that models of wickedness articulated and applied in criminal law should be evaluated critically. The judgment of the court constructed and responded to Knight as bad, a monster who is (and will always be) dangerous (especially to men) and ultimately irredeemable. Not only do monsters justify and require extreme measures, they also contaminate and undermine systems of orders - the judgments of Knight thus read more consistently with the genre of horror than that of law. The model of monstrous wickedness ostensibly works particularly well for women who kill, as it preserves the law's tendency to organise women as lacking agency. However, this model also generates a clash of binaries when applied to women. The monster/victim binary ascribes agency to the monster, generating difficulties for the law to reconcile the notion of a female monster with legal assumptions of the absence of female agency. This results in the problem of the female monster. The judicial creation of a horror movie monster that lacks basic humanity facilitates an abdication of the legal (and moral) task of judging a human being as human.

In February 2000, in Aberdeen, New South Wales, Katherine Mary Knight killed her lover, John Price. She then skinned and decapitated his corpse, and cooked parts of the body. Although Knight was charged with murder, the focus of the judgments of the courts was upon Knight's mutilation of the corpse. This article analyses how the courts constructed Knight's culpability. ${ }^{1}$ There are different ways of organising and articulating what it means to be wicked and culpable, and I argue that the courts constructed Knight's culpability as monstrous through an emphasis upon her transgressions of the borders of humanity and her malevolence. The choice and application of the model of monstrous wickedness have implications in terms of the type of legal responses available and required, the potential for contamination and the criminal law's construction of the legal subject.

Senior Lecturer, Faculty of Law, University of Technology, Sydney.

$R v$ Katherine Mary Knight [2001] NSWSC 1011; Knight v R [2006] NSWCCA 292. 
This article is a contribution to a relatively recent reinvigoration of the analysis of evil, ${ }^{2}$ in part due to the increased invocation of a political rhetoric of evil after the terror attacks of September $11 .{ }^{3}$ Criminal law theorists and practitioners tend to avoid or ignore normative accounts of the criminal law, and focus instead on the specifics of offences or concerns regarding claims of jurisdiction or authority, the organisation of social relations or the constitution of the legal subject. This avoidance of engaging with what it means to be wicked is consistent with a general trend noted by philosophers of wickedness, ${ }^{4}$ resulting in unexamined assertions and the application of narrow and/or weak models. I argue that a focus upon wickedness is consistent with a rich jurisprudential tradition seeking to articulate the criminal law as a system of blaming. This characterisation of the criminal law is not contentious; rather, it is consistent with the representation of the criminal legal system and practitioners of the system to themselves and also to a wider audience. ${ }^{5}$ The criminal law holds out its own practices as models of culpability, showing how and why persons are to be held accountable, on what terms, and who by. In doing so, it structures and sanctions a specific ordering of morality, fixing responsibility and representing culpability. ${ }^{6} \mathrm{~A}$ major question of the criminal law is that of blameworthiness: is the defendant sufficiently blameworthy or culpable to justify criminal sanctions?

Much criminal law is concerned with badness or petty wickedness, and philosophical accounts of wickedness assist in the examination and interrogation of the expression and ordering of culpability. Philosophies of wickedness highlight that wickedness does not exist independently or $a$ priori, but is constructed and expressed through discourses - including the $\mathrm{law}^{7}-$ and there are different models of wickedness available. ${ }^{8}$ The choice and application of different models have different implications. In this article, I draw upon Phillip Cole's models of wickedness outlined in The Myth of Evil, ${ }^{9}$ where he proposes four secular conceptions of wickedness: psychological evil, instrumental evil, pure evil and monstrous evil. I focus primarily on the intersection of the expression of monstrous wickedness and the construction of the legal subject, and examine the implications for a

2 For example, see Bernstein (2002), p 52; Cole (2006); Haybron (2002), pp 1-16; Morton (2004); Card (2002); Delbanco (1995).

3 One of the most famous recent examples of the reliance upon the rhetoric of evil was George Bush's reliance upon the notion of an Axis of Evil in his 2002 State of the Union speech.

4 Bernstein (2002); Cole (2006); Haybron (2002), pp 1-16; Midgley (1984/2001).

5 White (1978),

6 Garland (1990). See also Foucault (1975). Foucault examined the specific historical conditions through which questions of guilt and responsibility are organised leading to the construction of a (criminal) subject.

7 Davies (2008), p 373.

8 For example, Midgley (1984/2001) focuses upon a negative account of wickedness as an absence of goodness, while Card (2002) focuses particularly on harmful consequences.

9 Cole (2006). 
gendered subject. In Knight, we come up against the limitations of criminal law's conceptualisation of blame, responsibility and badness, revealing the need for more nuanced accounts of wickedness, and a critical awareness of the assumptions, costs and implications of different models of wickedness.

My analysis of the judgment of Knight has two major interlinked themes. In the first section of this article, I consider the way in which the majority judgments organised and expressed Knight's culpability in accordance with a model of monstrous wickedness. I argue that the judgment of the court constructed and responded to Knight as bad, a monster who is (and will always be) dangerous (especially to men) and ultimately irredeemable. The courts' emphasis upon Knight's transgression of borders and malevolence, and her unreasoning nature, reflected and reinforced the construction of Knight as monstrous. The reliance in the judgments upon the model of monstrous wickedness had implications for sentencing, and also the boundaries of the legal system. Not only do monsters justify and require extreme measures, they also have the potential to contaminate and undermine systems of orders - the judgments of Knight read more consistently with the genre of horror than that of law.

In the second section, I explore the implications of monstrous wickedness and gender configurations. I draw particularly upon Cole's explanation of monstrous evil, as this provides insight into the construction of Knight's culpability. Cole's exploration of the monstrous is important because it highlights the interrelationship of the construction of evil with questions of agency. By 'agency', I mean a shorthand term denoting ideas about the capacity to act in a rational or purposive manner. I demonstrate how the model of monstrous wickedness ostensibly works particularly well for women who kill, as it preserves legal assumptions of feminine passivity When women kill, their behaviour is regarded as needing to be explained, and this is done either through a discourse of victimisation and/or one of madness. ${ }^{10}$ Both these subject positions ascribe limited agency due to either circumstances or irrationality. Similarly, the role of monstrous evil (ostensibly) prescribes limited agency to characters. Monsters are inscribed as irrational, malevolent creatures that want our suffering, requiring extreme responses in order to reinstate the boundaries they have challenged. However, this model also generates a clash of binaries when applied to women. The monster/victim binary ascribes agency to the monster, generating difficulties for the law to reconcile the notion of a female monster with legal assumptions of a lack of female agency. Should we create a category of the monstrous victim, allowing multiple subjectivities, with Knight occupying the position of both victim and perpetrator? Or should the model of monstrous wickedness be removed from the repertoire of the criminal law?

The law enunciates and applies models of wickedness when attributing blameworthiness, and we should critically evaluate the models and their implications. I argue, in accordance with Cole, that monstrous wickedness is

\footnotetext{
Sheehy, Stubbs and Tolmie (1992), p 387.
} 
based on a model that is overly simplistic, draws upon fiction and trivialises wickedness. It requires an excessive response and potentially contaminates the law whilst simultaneously providing an occasion to reaffirm the legal order. The category of monster signifies problems in understanding and the treatment of wrongdoers, particularly women who kill. Zizek has argued that monsters are a fantasy scenario that obfuscates the true horror of a situation. ${ }^{11}$ I maintain that the legal construction of Knight as a horror movie monster who lacks basic humanity results in an abdication of the legal (and moral) task of judging her as human.

My focus of analysis is upon the legal construction of Knight's culpability, rather than on the coverage of the case by the media, on the internet and in 'true crime' books, which also contribute to conceptions of culpability. ${ }^{12}$ Meaning is socially produced and the criminal law is a powerful discourse in the construction of the notion of what it means to be bad or wicked. I place the legal judgments of Knight at the centre of my analysis, and supplement this analysis with an examination of fictional representations of monsters. This is because monsters are typically associated with fiction. These works of imagination provide a detailed account of the problem of evil, and a template of necessary and justified responses. Analysis of law through and with fiction emphasises that notions of wickedness are constructed or created. Accordingly, I embrace the idea that both law and literature are acts of creation. This conjunction of law and literature is particularly apparent in philosophies of wickedness. Almost all philosophies of wickedness utilise criminals and fictional characters as their primary basis for theorising. ${ }^{13}$

I examine three judgments of Knight. Justice O'Keefe was the sentencing judge at first instance, and sentenced Knight to life imprisonment - the first time such a sentence had been imposed on a woman in Australia. On appeal, Chief Justice McClellan (with whom Latham J agreed) held that the sentence imposed by Justice O'Keefe was appropriate. McClellan CJ quoted Justice O'Keefe's judgment at length, with fifteen of the nineteen pages of his judgment a direct quote from the judgment at first instance. Throughout the article, I will refer to these judgments as the majority. In a minority judgment, Justice Adams held that there was not an error in the judgment of O'Keefe J; however, he stated that he would not have imposed a life sentence on Knight, but instead the possibility of parole in 33 years. All three judgments utilise a lexicon of wickedness. O'Keefe J (quoted by McClellan CJ) refers to Knight's 'evil acts', ${ }^{14}$ while Justice Adams talks of her 'moral culpability or (to use an old-fashioned term) the wickedness that

\footnotetext{
Zizek (1999) p 91.

For example, see Lee (2002); Lalor (2002).

For example, Midgley (1984/2001) analyses war criminals such as Eichmann, and fictional creations such as Mephistopheles, Hyde and Iago. Flahault (2003) focuses upon Frankenstein in his meditation on malice. Neiman (2002) includes Eichmann and Oedipus.

${ }_{14} \quad$ Knight $v R$ [2006] NSWCCA 292 (11 September 2006) at 24; $R v$ Katherine Mary Knight [2001] NSWSC 1011 (8 November 2001) at 111.
} 
was involved'. ${ }^{15}$ McClellan $\mathrm{CJ}$ and Adams $\mathrm{J}$ also considered her to be guilty of 'heinous' acts - a word used to denote odious, highly criminal acts. There is also much emphasis in the judgments upon Knight's malice - a term historically utilised in criminal law to denote wickedness. ${ }^{16}$ I contribute to research on the philosophies of wickedness by demonstrating the ways in which models of wickedness from fiction are reflected and reinforced in legal constructions of blameworthiness.

\section{Facts of the Case}

After realising that her de facto, Price, was planning on finishing their relationship, Knight stabbed him at least 37 times in various parts of both the front and back of his body using a butcher's knife. Through an analysis of blood stains, it was established that Price was first attacked in the master bedroom, then in the hallway as he attempted to escape Knight. He succeeded in getting outside but was then either dragged or returned to the house and fell in the hallway quite close to the doorway that led into the lounge room, where his body was later found by the police.

After Price had died, Knight then dragged his body from the hallway into the lounge room and skinned it. 'This was carried out with considerable expertise and an obviously steady hand so that his skin, including that of his head, face, nose, ears, neck, torso, genital organs and legs, was removed so as to form one pelt.' ${ }^{17}$ Knight then hung the pelt on a meat hook on the architrave of the door of the lounge room before decapitating Price's body and arranging it with the left arm draped over an empty soft drink bottle, and the legs crossed. Knight also removed parts of his buttocks and took the 'excised parts of Mr Price' to the kitchen and made a 'sickening stew' in a large pot with his head, and freshly peeled and prepared vegetables. ${ }^{18}$ The pieces cut from Price's buttocks were baked in an oven with other peeled vegetables and then arranged on plates together with the baked vegetables as meals for Price's son and daughter. A third piece was thrown on the back lawn - whether for consumption by dogs or for some other reason was not revealed in the evidence. Knight claimed that she had suffered abuse as a child and adult, and that her relationship with Price was violent. Psychologists accepted that Knight had a borderline personality disorder.

The court described the circumstances of the case as 'horrendous'. ${ }^{19}$ Knight claimed that she could remember nothing of the aftermath of the killing, pleaded guilty to murder, and was sentenced to life imprisonment. The court held that this was within the most serious category of murders due to her premeditation and enjoyment of the acts of defilement. Her 'evil actions' indicated cognition, volition, calm and skill. At no time did she

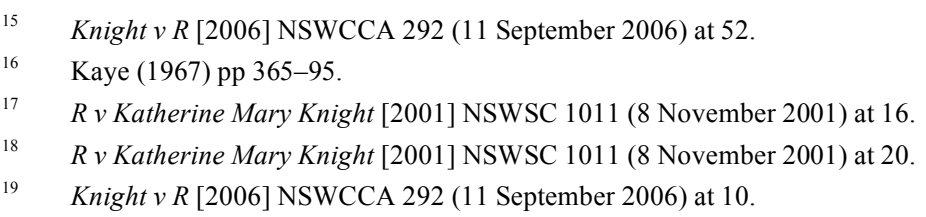


express any remorse or regret for what she had done. Knight was unsuccessful in her later appeal against the life sentence. ${ }^{20}$

\section{Constructing Monsters: Transgressing Borders and Malevolent Intent}

The majority judgments constructed Knight as monstrous, rejecting any nuances that might have complicated the notion of Knight's culpability, preferring to reduce her motives to irrational intent and malevolence, rejecting any past victimisation, and explaining her actions as due to her 'nature'. In this section I consider how the judgments organise and express Knight as wicked. I argue that the model of monstrous wickedness communicated in the judgments of the court constructed and responded to Knight as bad, a monster who is (and will always be) dangerous (especially to men) and ultimately irredeemable. According to the monstrous conception, those who are willing to inflict suffering on others purely for its own sake are monsters in human form. They are capable of pure evil precisely because of their monstrosity. These monsters constitute a different class of humanity - they are not like you and me. This conception of evil tends to be portrayed in fiction, with villains and/or monsters with superhuman powers filled with malevolence towards us, but is also present in political rhetoric and media representations of some criminals. ${ }^{21}$ This conception considers evil to be beyond the limits of humanity - beyond explanation, incomprehensible to normal human beings. I then go on to consider the implications for monstrous wickedness in terms of sentencing and the boundaries of the legal system.

\section{Transgressing Borders}

The central theme of monstrous evil is the transgression of borders of humanity. Monsters are conceptualised as beyond understanding, as incomprehensible to human beings. This theme of transgressing borders has been explored from a variety of different perspectives and disciplines. Derrida framed the idea in terms of undecidability; ${ }^{22}$ Mary Douglas considered pollution and contamination fears of disorder from an anthropological perspective; ${ }^{23}$ Kristeva explored the idea of abjection in The Power of Horror: 'It is thus not lack of cleanliness or health that causes abjection but what disturbs identity, system, order. What does not respect

\footnotetext{
$20 \quad$ Knight $v R$ [2006] NSWCCA 292 (11 September 2006).

21 Cole (2006), pp 13-16.

22 The classic monsters of horror films, zombies, have been used to explain Derrida's ideas about undecidability. Zombies might be 'EITHER alive OR dead. But it cuts across these categories: it is BOTH alive AND dead. Equally, it is NEITHER alive NOR dead, since it cannot take on the "full" senses of these terms ... in terms of life and death, it cannot be decided.' See Collins and Mayblin (1996), pp 17-20.

23 Douglas (1966/2002).
} 
borders, positions, rules. The in-between, the ambiguous, the composite. ${ }^{24}$ While there are significant differences in these theories, each of these perspectives stresses the idea that the disorderly, abject or undecidable disturbs, transgresses or undermines identity, system and order. The different theoretical analyses of the monstrous, disorderly, abject or undecidable emphasise the fear and fascination they generate because of their potential to challenge our cherished borders. We fear the monstrous because of its potential to contaminate and undermine cherished borders, to blur and weaken dividing lines that affirm binary relations. This is because monsters not only break rules and cross borders, but also challenge the border itself, by being both and neither one thing and another. The monstrous contaminates the crime scene and the legal system, highlighting the fragility of the law.

The idea of transgressing borders is essential to the construction of the monstrous in the horror film. The specific nature of the border may change from film to film, but the function of the monstrous remains the same: to bring about an encounter between the symbolic order and that which threatens its stability. ${ }^{25}$ The monstrous is produced at the borders - the border between the living and the dead $;{ }^{26}$ man and beast; ${ }^{27}$ good and evil $;{ }^{28}$ or the monstrous is produced at the border that separates those who take up their proper gender roles and those who do not ${ }^{29}$ - sane and mad. ${ }^{30} \mathrm{I}$ will explore the various ways in which the judgments asserted that Knight had transgressed significant borders.

\section{Fiction and Reality}

One border transgressed by Knight was the one between fiction and reality. The judgments accept that Knight was inspired by the horror film Resurrection. The blurb for the film was 'WARNING: Most mind blowingly shocking film you will see this year', and the movie was rated R18+ with medium-level violence. It was directed by the director of Highlander, Russell Mulcahy, and stars Christopher Lambert as Detective John Prudhomme. The slayer kills 33-year-old males with the names of apostles each Friday, carving verses of the Bible into their flesh. Each time, he removes a body part with 'almost surgical precision' in order to create a body of the dismembered parts for the resurrection of Christ. He needs the blood of a newborn baby boy born at midnight of a mother named Mary, and it is his routine/predictability that is his downfall. Detective Prudhomme saves the baby (and in the process himself), and shoots the slayer. Rather than viewing the film, Justice O'Keefe accepted the psychiatrist's evaluation

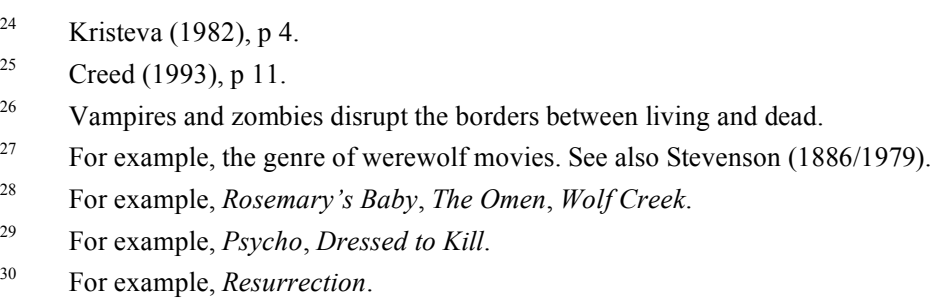


that Knight enjoyed 'macabre', 'disturbing and gruesome' videos. For Justice O'Keefe, simply watching horror films was an indicator of Knight's disturbed nature. However, for horror film fans (including myself), Resurrection is not particularly graphic or horrifying. Much of the killing takes place off screen, with the focus instead on the (late) arrival by the police to an abject scene organised by the perpetrator. The first violence on screen is by the police against one of their own.

Technically, the film is rated as a thriller rather than horror in the video store. ${ }^{31}$ What is horrifying, however, is Knight's crossing over the border of fantasy into reality. Resurrection was 'not only extremely violent, but directly related to the charge against the prisoner. That video gave to the actions by the prisoner in relation to Mr Price's body a sense of "copy cat". ${ }^{32}$ The film 'depicted gruesome murders, decapitation, a skinned body and the hanging of a body on a meat hook. ${ }^{33}$ Knight repeated scenes from Resurrection in her organisation of the crime scene. Much has been written about the pleasure and fears of the fictional representation of crime - the production of crime as entertainment. ${ }^{34}$ In her analysis of detective fiction, Young notes the pleasure of the self-administration of fear and suspense..$^{35}$ Audience members attempt to predict which horror films will provide an acceptable dose of fear and abjection, and are comforted by the sense that, whatever happens, the excursion into the fearful world of criminality and evil will be followed by a return from fear. In the case of detective fiction, this is usually through revealing the identity of the criminal and some kind of retribution. In horror films, the monster may be killed or stopped, but part of the enjoyment for a true horror fan is that a (good/bad) monster is not killed (enough) to prevent re-emergence in a sequel. The comfort for a horror fan is that the scenes and monsters represented are fictional, representing the non-existent bogey-man, alien, undead/dead. Knight crossed this border, importing scenes from Resurrection into her crime scene. In Resurrection, the third body is decapitated and the headless corpse is seated on the toilet. The slaying, skinning, decapitation and arrangement of the corpse by Knight were inspired by fantasy.

Not only was Knight inspired by fantasy, but she brought the pleasure of fantasy into her crime scene. 'The last minutes of his life must have been a time of abject terror for him, as they were a time of utter enjoyment for her. ${ }^{36}$ The court emphasised that she took 'perverted pleasure' in the killing and mutilation of Price. ${ }^{37}$ She derived 'satisfaction' from 'committing quite

\footnotetext{
31 See Clover (1992) regarding her methodology of accepting video store categories as the basis for her research on horror films.

$32 \quad R v$ Katherine Mary Knight [2001] NSWSC 1011 (8 November 2001) at 70.

$33 \quad R v$ Katherine Mary Knight [2001] NSWSC 1011 (8 November 2001) at 67.

$34 \quad$ Naffine (1997); Young (1996), Ch 4.

$35 \quad$ Young (1996), p 79; Young (2009).

$36 \quad R v$ Katherine Mary Knight [2001] NSWSC 1011 (8 November 2001) at 112.

$37 \quad R v$ Katherine Mary Knight [2001] NSWSC 1011 (8 November 2001) at 71.
} 
cruel acts', ${ }^{38}$ 'she enjoyed doing what she did' ${ }^{39}$ and 'she enjoyed doing what she was doing as she skinned and dismembered Mr Price and cooked parts of his body' ${ }^{40}$ For some, her enjoyment and pleasure in cruelty places her beyond the borders of humanity. For example, Thomas Hobbes stated 'that any man should take pleasure in other men's great harmes, without other end of his own, I do not conceive possible' ${ }^{41}$ This assumes that humans will not take pleasure in evil for its own sake, and thus Knight transgressed another border through her enjoyment. ${ }^{42}$ Knight's actions disrupt the association of crime with fear and horror, instead emphasising the pleasure of crime - a pleasure usually intertwined with the realm of fiction rather than reality. She transgressed the border between reality and fantasy, and imported inappropriate affect into the crime scene.

\section{Borders of Law}

In addition to transgressing the border between fantasy and reality, much of Knight's behaviour not only broke the law, but was also at and beyond the borders of the law. Crime disturbs the system of law; it undermines law and order while also providing an opportunity to reaffirm the legal order. In killing Price, Knight transgressed the border between life and death, demonstrating the fragility of this border. ${ }^{43}$ However, it is not the killing that is focused upon in the judgments in the construction of Knight's wickedness - homicide does not always result in an attribution of monstrous wickedness. Rather, the judgments are concerned with what occurred at and beyond the borders of the law. The spatial imagery in the judgments reiterates this theme of acting 'outside' the law. McClellan CJ stated that: 'This was an appalling crime almost beyond contemplation in a civilised society. ${ }^{{ }^{4} 4}$ Great emphasis was placed upon her history of violence in past relationships, but it was noted that Knight had no criminal record. Her behaviour was thus both illegal and legal - never prosecuted, but subject to the potential of prosecution. Even the violence in the relationship with Price occurred outside of the law. When Price called the police to eject Knight from the house in the days before the killing, the police refused, advising Price to get an Apprehended Violence Order (AVO). Price sought an AVO just before the murder, stating that he wished to end his relationship with her and prevent her from entering the house. This AVO was not effective in

\footnotetext{
$38 \quad R v$ Katherine Mary Knight [2001] NSWSC 1011 (8 November 2001) at 78.

$39 \quad R v$ Katherine Mary Knight [2001] NSWSC 1011 (8 November 2001) at 80.

$40 \quad R v$ Katherine Mary Knight [2001] NSWSC 1011 (8 November 2001) at 71.

41 Hobbes (1651/1991), p 126.

42 In contrast, Freud (1930/1975) thought it was quite natural that we would sometimes take delight in the suffering of others who are strangers to us.

43 In contemporary law, this is expressed as a secular border, but historically an unnatural slaying was an evil in and of itself, causing tainting to the slayer and potentially the community, requiring expiation. See Finkelstein (1973), pp 169-290; Fletcher (1978).

$44 \quad$ Knight $v R$ [2006] NSWCCA 292 (11 September 2006) at 45.
} 
protecting Price from Knight, highlighting the fragility of the law's boundaries, the inability to intervene in time.

Knight's actions highlighted the tardiness of the law - she had months of planning before the killing itself. ${ }^{45}$ The judgments asserted that Knight's premeditation was particularly relevant to her culpability:

The level of culpability of the prisoner is, as I have determined, extreme. The murder was premeditated. The prisoner not only decided to murder Mr Price, but planned the timing and what she was going to do in a manner which left open to her, as she thought, a way of escaping punishment, namely that she would be considered as mad. ${ }^{46}$

Knight had indicated an intention to kill Price many months prior to the murder, including saying to one of her daughters that 'I told him if he took me back this time it was to the death' ${ }^{47}$ Price had also previously expressed fear that Knight would kill him. The court accepted that the trigger for the murder was 48 hours prior to the slaying. Knight's behaviour demonstrates the links between premeditation and abjection, as her premeditation disrupted meaning and heightened the display of the fragility of the law. ${ }^{48}$ This is because the time prior to the murder was one of pretence - she presented positively and lawfully even whilst planning murder.

This idea that Knight's actions were beyond normal humanity and the law was also highlighted in reactions to the case. On hearing the facts of the case, the first question I was consistently asked was where the case had happened. My Australian colleagues assumed the case was either fictional or had occurred somewhere else, usually America. It was beyond contemplation that this could occur in rural Australia.

\section{Defilement of the Corpse}

It is Knight's defilement of the corpse in particular that illuminates her disruption of the boundaries of the law. Her treatment of the corpse was so far beyond the law that it was not explicitly the subject of statutory prohibition, ${ }^{49}$ nor was she charged with any offence relating to her treatment of the corpse. As Knight argued on appeal, the focus in sentencing upon her actions after the slaying was irrelevant to the charge of murder. To disrupt the narrative of the monstrous, Knight attempted instead to normalise her

\footnotetext{
45 Rush (1997).

$46 \quad R v$ Katherine Mary Knight [2001] NSWSC 1011 (8 November 2001) at 87.

$47 \quad R v$ Katherine Mary Knight [2001] NSWSC 1011 (8 November 2001) at 46.

$48 \quad$ Kristeva (1982), p 4.

49 The Crimes Act 1900 (NSW), s 81C criminalises 'misconduct with regard to corpses' with a maximum penalty of two years' imprisonment; however, there is no offence of cannibalism. The absence of an offence of cannibalism could arguably be not because of a failure to contemplate its possibility, but rather due to a fear of producing the very deviance that is feared. This argument has been made in relation to the English legal system's response to lesbianism: Hart (1994).
} 
actions, asserting it was all too normal for a person to kill their lover, that this was 'a common domestic murder'. Adams J rejected her argument:

Although at first I was minded to think that too much had been made of her subsequent dealings with Mr Price's body, I have concluded, on reflection, that so extreme was this conduct and so closely linked in time and place was it with the killing that it must be regarded as an integral part of the killing itself. ${ }^{50}$

Despite the focus of the judgments, the defilement of the body was not the subject of charges; it was beyond the classificatory systems of law. The judges were compelled to consider actions that were beyond the formal boundaries of the law, reiterating the idea of Knight as monstrous. Monsters are conceptualised when (legal) categories are exhausted. In this case, her acts were so heinous as to be beyond the law.

It is through the focus upon Knight's treatment of the corpse that Knight is inscribed as monstrous. Knight's removal of Price's skin was described by the court as a 'rite of defilement'. The word 'rite' denotes something which is repeated, emphasising the majority perspective that the killing and defilement of Price was consistent with Knight's past behaviour and character. The removal of Price's skin literally transgressed the border between the visible, knowable outside of the body and its secret insides. This is a border that is in the form of one thin membrane, "protected only by a collective taboo against its violation'. ${ }^{51}$ The removal of Price's skin undermined the clean and proper body. 'Many of the wounds were deep, and extended into vital organs. These included the aorta, both lungs, the liver, the stomach, the descending colon, the pancreas, and the left kidney, the lower pole of which had virtually been sliced off. ${ }^{52}$ Knight saw, and enabled others to see, the 'opened' body.

In addition, Knight used her skills as an abattoir worker to remove Price's skin. 'This was carried out with considerable expertise and an obviously steady hand so that his skin, including that of his head, face, nose, ears, neck, torso, genital organs and legs, was removed so as to form one pelt. ${ }^{53}$ Knight then hung the pelt on a meat hook on the architrave of the door of the lounge room. She treated the human body like an animal's, demonstrating the fragility of the border between humans and animals. ${ }^{54}$ Also, despite attempts by the court to reinstate Price's identity, the court too was contaminated, using the word 'pelt' - a word usually associated with animal skins - to describe Price's skin.

\footnotetext{
Knight v R [2006] NSWCCA 292 (11 September 2006) at 64.

Clover (1992), p 32.

$R v$ Katherine Mary Knight [2001] NSWSC 1011 (8 November 2001) at 9.

$3 \quad R v$ Katherine Mary Knight [2001] NSWSC 1011 (8 November 2001) at 16.

$54 \quad$ Nussbaum (1999).
} 
The treatment of Price as food further transgressed the border between humans and animals. Knight treated Price as we would cuts of meat. Knight cooked Price's head to produce a 'sickening stew':

The pieces which had been cut from Mr Price's buttocks were baked in the oven of the premises by the prisoner together with other of the vegetables she had peeled. The gruesome steaks were then arranged on plates together with the vegetables she had baked and left as meals for the son and daughter of the deceased, accompanied by vindictive notes to each in the handwriting of the prisoner. A third piece was thrown on the back lawn, whether for consumption by dogs or for some other purpose is not revealed in the evidence. ${ }^{55}$

It is unclear whether Knight ate part of Price's body, and the judgment does not speculate. It is clear, however, that she did treat him as food. Food loathing is a major source of abjection, and in horror films this is frequently represented - especially through eating human flesh. ${ }^{56}$

Knight's treatment of Price's corpse disrupted and undermined his identity: 'The prisoner decapitated Mr Price's body and at some stage arranged it with the left arm draped over an empty soft drink bottle, and the legs crossed. This was said in evidence to be an act of defilement demonstrating contempt for Mr Price's remains. ${ }^{57}$ In decapitating Price she removed his identity - a person's face is a means by which we recognise them. She made Price her plaything. She then sustained this disruption of his identity with the removal of his skin, leaving only her marks upon him:

On another occasion she sliced Mr Price's left chest with a knife. The scar from this was still visible on his body following his death and skinning. It is perhaps not coincidence that the only part of Mr Price that was not skinned by the prisoner was that part of him which bore the scar which she inflicted. ${ }^{58}$

Knight left her mark on Price's body - she exercised ownership of him. She transgressed the border between self and other, invading and subsuming Price, and perhaps absorbing him.

\section{Unreasoning Malevolence}

Another indication that Knight was constructed as monstrous (or pure evil) was the emphasis in the majority judgments upon her malevolence. The

$R v$ Katherine Mary Knight [2001] NSWSC 1011 (8 November 2001) at 21.

$56 \quad$ For example, see the Hills Have Eyes, The Corpse Grinders. The human-sausage theme in Texas Chainsaw Massacre I hints at it, while in Texas Chainsaw II there is a statewide chilli-tasting contest, and the family is richer due to their success in the (human) sausage making business.

$57 \quad R v$ Katherine Mary Knight [2001] NSWSC 1011 (8 November 2001) at 16.

$58 \quad R v$ Katherine Mary Knight [2001] NSWSC 1011 (8 November 2001) at 38. 
motives of monsters are beyond understanding, incomprehensible to human beings, and it is this inability to explain that leads to the use of the concept of monstrous wickedness. ${ }^{59}$ Monsters are figures of pure malevolence who want nothing other than our suffering and destruction. The majority judgments accepted that Knight's acts were committed for no reason; her actions were deemed incomprehensible to 'normal' human beings, with the judgments musing that she did this because of her 'nature', her 'violent personality'. However, there were other ways of exploring and constructing Knight's culpability that did not rely upon the model of monstrous evil, and these alternatives were available in the judgments. These alternatives did not emphasise Knight's malevolent, unreasoning nature.

The first alternative is a psychological conception of wickedness, which asserts that where humans commit what would be described as evil acts, there must be an explanation that does not involve them freely or rationally choosing those actions. This model assumes such acts are committed through either necessity or madness, ${ }^{60}$ and can thus be characterised as a denial of the possibility of evil freely chosen, a lack of agency. As I argue below, this idea that a perpetrator was a victim of circumstances or madness is a particularly common argument for female offenders. Knight sought to portray herself as a victim of sexual abuse by her brothers, and as a victim of violence in her marital and de facto relationships. The court rejected her claims of sexual abuse and determined that even if she had been the victim of physical abuse, she 'gave as good as she got'. The possibility of violence in the relationship between Knight and Price was barely entertained by the court; her earlier visit to the doctor with injuries was seen as part of her attempts to 'set the scene'. Knight's claims that she was a victim of madness were also unsuccessful. Two of the three psychiatrists asserted that Knight had a borderline personality disorder, but that this did not preclude agency, control or cunning - instead: 'The personality problems demonstrated in the history of Ms Knight's life are not in my view psychiatric disease - they are her nature ... The main effect of Ms Knight's personality problems was to cause difficulties for others. ${ }^{61}$ These findings precluded describing Knight's behaviour as mad, and established the authority of the courts to judge her as a competent legal subject.

In addition, there was potential in the judgments to organise Knight's culpability according to the model of instrumental evil. According to this perspective, humans cannot be evil in the pure sense of willing suffering on others for its own sake, but they are capable of impure evil, which is the infliction of suffering upon others for some human end, such as wealth, security or power. ${ }^{62}$ An evil person is willing to make others suffer in order to achieve their goal, but the goal is distinct from the suffering. This model

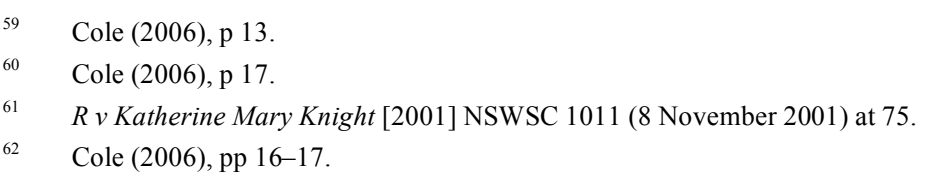


accords agency to the actor - a person can make choices (albeit bad ones) to achieve certain ends. In sentencing Knight to life imprisonment, Justice O'Keefe stated:

I am satisfied beyond reasonable doubt that her evil actions were the playing out of her resentments arising out of her rejection by $\mathrm{Mr}$ Price, her impending expulsion from Mr Price's home and his refusal to share with her his assets, particularly his home, which he wanted to retain for his children. ${ }^{63}$

On this account, Knight chose to kill Price because he would not leave her the home and he planned to finish the relationship. Thus she could be characterised as acting purposefully to achieve certain ends, such as vengeance, or to prevent Price from leaving her. Moreover, her desire to be seen as mad could provide a reason for her treatment of Price's corpse. However, the model of instrumental evil is not dominant in the majority judgments of Knight. In contrast, in keeping with the monstrous model of wickedness, the majority judgments placed great stress upon Knight's 'utter enjoyment' in the final minutes of Price's life. This enjoyment is inconsistent with the instrumental model, which stresses that the suffering of others is not a goal of the act, only a necessary means towards achieving something else. ${ }^{64}$

Not only did the majority judgments minimise any reason for Knight's slaying of Price; there was a persistent refusal throughout the majority judgments to accept any reasons for her past behaviour except malice or spite. This can be seen in the court's response to Knight's claims of violence and bad treatment at the hands of her de facto husband, David Saunders:

\begin{abstract}
In particular, she claimed that on one occasion he had kicked her in the stomach at a time she thought she was pregnant, as a consequence of which she got a knife and went immediately into the back yard and as an act of revenge cut the throat of Mr Saunders' eight week old puppy whilst Mr Saunders was watching. On a later date the prisoner damaged Mr Saunders' car. It was at about this time that she took an overdose of sleeping tablets and was admitted to a psychiatric hospital. ${ }^{65}$
\end{abstract}

She took out a number of AVOs against Saunders. In contrast, Saunders claimed their relationship was 'basically good', and that it was Knight who had assaulted him:

Whether Mr Saunders was the aggressor in the relationship is not able to be resolved satisfactorily on the evidence before the court. However, what is clear and uncontradicted is that there were a

\footnotetext{
63 R v Katherine Mary Knight [2001] NSWSC 1011 (8 November 2001) at 75.

${ }^{64}$ Cole (2006), pp 16-17.

65 $\quad R v$ Katherine Mary Knight [2001] NSWSC 1011 (8 November 2001) at 31.
} 
number of violent and vengeful acts by the prisoner toward $\mathrm{Mr}$ Saunders and his property and these included an instance in which a stabbing instrument was used to inflict injury and another in which she killed a puppy by cutting its throat as an act of malice and revenge directed at Mr Saunders. ${ }^{66}$

Similarly, Knight claimed that her relationship with Chillingworth was also violent. The court accepted that Chillingworth was addicted to alcohol at the time of their relationship. 'Mr Chillingworth's statement reveals a number of spiteful and vindictive acts, including the smashing of his false teeth because it was claimed that he had smacked one of the daughters of the prisoner - a claim which he denies. ${ }^{67}$

Knight's explanations for past violence tended to revolve around the protection of her children or herself. The court ignored evidence by one of Knight's daughters that Saunders had been violent towards Knight. Knight's history of relationships could have been organised according to the instrumental conception of evil where she used violence to achieve specific ends. Admittedly, Knight exercised imaginative and extravagant acts of revenge, but this does not preclude the possibility that her violence was a response to abuse. However, the majority preferred to regard Knight as acting without any reason or justification except a preference to inflict suffering. This precluded any instrumental reasons for her behaviour. For example, Adams $\mathrm{J}$ asserted that the 'extraordinary extent of the applicant's brutality, and perhaps of greater significance, her lack of what we might recognise as humane feelings, which were, I think, completely buried in unreasoning and irrational hatred for her victim' were relevant. ${ }^{68}$ For the majority, there was never, nor could there ever be, any reason for doing what she did. She was unreasoning.

In contrast, the minority judgment by Justice Adams allowed for more complexity in the construction of Knight's culpability. Adams J expressed doubt about the ability of psychiatrists to evaluate actions like Knight's defilement of Price's corpse. He noted that 'such patients are, thankfully, very rare. Experience of them must necessarily be limited.' This scepticism caused Adams $\mathrm{J}$ to question the psychiatric evaluations wholeheartedly accepted by the majority of Knight as uniformly and consistently dangerous and wicked. Rather than attempting to construct Knight as inherently and consistently violent and dangerous, Adams $\mathrm{J}$ asserted that there was a qualitative difference between effect and culpability of Knight's past actions compared with the murder of Price. He also rejected the idea that the prisoner had such great enjoyment of the murder and mutilation of $\mathrm{Mr}$ Price. ${ }^{69}$ This allowed Adams J some space to organise Knight's culpability according to the model of instrumental evil. Even though her reasons were

\footnotetext{
66 $\quad R v$ Katherine Mary Knight [2001] NSWSC 1011 (8 November 2001) at 34.

${ }_{67} \quad R v$ Katherine Mary Knight [2001] NSWSC 1011 (8 November 2001) at 35.

$68 \quad R v$ Katherine Mary Knight [2001] NSWSC 1011 (8 November 2001) at 64.

69 $\quad R v$ Katherine Mary Knight [2001] NSWSC 1011 (8 November 2001) at 50.
} 
not sufficient to justify what she did, they did provide some explanation that is, while her actions were wrong, they were still those of a human exercising choice - albeit bad choice.

\section{Implications of Monstrous Wickedness}

\section{Sentencing}

The reasoning justifying the imposition of life imprisonment is consistent with the implications of monstrous wickedness: $:^{70}$

This was an appalling crime almost beyond contemplation in a civilized society. The applicant determined to kill the deceased in a violent manner inflicting multiple deep wounds and after his death set about mutilating his body and in a macabre manner presented portions of it as a meal for his children. The crime was the product of a violent personality intent upon claiming the life of her de facto in a relationship which was plainly failing. She expressed no remorse or contrition. The psychiatric evidence indicates that her personality is unlikely to change in the future and, if released, she would be likely to inflict injury, perhaps death on others. The deceased's family may be at particular risk. ${ }^{71}$

This belief in her future dangerousness suggests that, unlike mere mortals, Knight will not weary with age. Even in her seventies, she would remain dangerous. $^{72}$ The exclusion of any explanation for her behaviour means that redemption is impossible. Knight was inscribed as consistently dangerous and malevolent - both in the past and future. This generalised malignant intent meant that she was perceived as dangerous to the family, to men and to society generally. 'Were she to be released into the community at any time she would be likely to inflict serious injury, perhaps death and even mutilation, on those who cross her. ${ }^{73}$ The court majority constructed a character that was a (born) monster, wanting nothing more than our extreme suffering and destruction.

70 The primary focus of my analysis is upon the reasoning justifying life imprisonment, rather than the sentence itself. However, sentences of life imprisonment are relatively rare in New South Wales. 17.1 per cent of people found guilty of homicide between adult sexual intimates were given life imprisonment between 1988 and 1990, even though at that time such a sentence for murder was mandatory unless the judge found reduced culpability. In addition, female offenders received lesser sentences than males: Easteal (1993). More recent research indicates that the average sentence for murder is approximately fifteen years. For example, the average sentence for murder in 1999 was 154.9 months, and in 2007 it was 183.9 months. See Lulham and Fitzgerald (2008), p 4.

$71 \quad R v$ Katherine Mary Knight [2001] NSWSC 1011 (8 November 2001) at 20, per McClellan CJ.

72 This is similar to the characterisation of Myra Hindley, demonstrated through the continued reliance upon her 'mugshot' taken decades earlier. See Young (2000), pp 241-65.

$73 \quad R v$ Katherine Mary Knight [2001] NSWSC 1011 (8 November 2001) at 85. 
Monstrous evil demands and justifies extreme measures. Theorists note our desire to resolve undecidables, disorder and the abject, whether expulsion or exclusion, to reassert boundaries, rules and law. For example, vampires require stakes through the heart and perhaps burning; zombies can only be finished off by decapitation. ${ }^{74}$ In the case of Knight, the majority regarded life imprisonment - the most extreme response available - as necessary and justified. Life imprisonment imposed a literal and symbolic boundary upon Knight. With no possibility of release or redemption, or change in her situation apart from death, the life sentence resolves and exiles her, rendering her place in/out of society certain, so the community and law do not need to reside in the zone of undecidability.

In contrast, Adams $\mathrm{J}$ asserted that, with age, Knight may no longer be a danger to society:

She is now almost 51 years of age. Were I considering the matter afresh, I would have imposed an overall sentence of 45 years with a non-parole period of 33 years. This would have had the effect of enabling the applicant to be considered for release on parole when she was 77 years of age. I think that the Authority and the Council would be well qualified to make an appropriate assessment as to whether she could then be released and, if so, on what conditions. ${ }^{75}$

Justice Adams thus emphasised that Knight, like all humans, would grow older. As such, she would be likely to become less dangerous to the community, and it would be appropriate to leave questions of dangerousness to experts in the future, rather than to assume that she was inherently dangerous.

\section{Contamination of the Crime Scene}

We fear the monstrous because of its potential to contaminate and undermine cherished borders, to blur and weaken dividing lines that affirm binary relations. Monsters render fluid what we understand to be fixed. They destabilise fundamental cultural dichotomies such as life/death, human/inhuman. If these basic distinctions are not operative, than neither are other cherished binaries. ${ }^{76}$ Knight's actions undermine assertions of the autonomy and closure of law ${ }^{77}$ as the judgment is contaminated by Knight's actions and reads more like a horror story than a crime scene. Horror films wallow vicariously in normally taboo forms of behaviour before restoring order. They are saturated with scenes of blood and gore, pointing to the fragility of the body. In Resurrection, blood is smeared across the walls and floors where the killing took place. Knight copied the killer in Resurrection

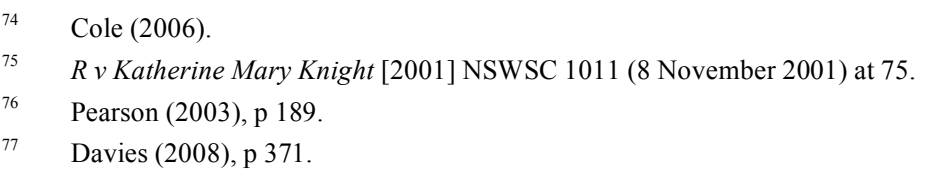


and bled Price before arranging his corpse on the couch. The judgments in Knight dwell on the blood of the victim, fascinated by the loss of a great deal of blood, the 'smearing of blood' ${ }^{78}$ the blood stains 'splattered and smeared throughout various parts of the house and in a pool' ${ }^{79}$ as well as on the floor where the killing took place. The blood stains provided 'graphic and disturbing evidence' of the process of the slaying. ${ }^{80}$ Justice O'Keefe was concerned about the effect of such 'graphic' evidence on potential jurors, an issue that was avoided due to Knight's guilty plea on the first day of trial.

The judgment can be read as an attempt for the court to reassert control over the crime scene to restore the law. Through premeditation, Knight controlled the crime scene, knowing the effect that decapitation would have on police from the horror film. In Resurrection, the police arrive after the murders to a crime scene organised by the killer. The camera dwells on the effect of the scene on the police. The decapitated corpse excites particular horror in the police officers:

Oh my God. Oh my God. Oh my God. What's this guy got, a chopping list or something? Where's his head? There's a guy sitting in front of me having a crap, and his head's gone. Where's his head? I have never seen anything like this, never. ${ }^{81}$

The judgment refers to the effect of the killing Price as 'horrendous', 'beyond the experience of any of the professional people'. 'A number of police officers who were highly experienced in examining crime scenes found the need to take stress leave because of the situation with which they were confronted when examining the crime scene at Mr Price's house. ${ }^{82}$ Knight controlled the abject scene, infiltrating and contaminating the criminal event in such a way that the judgments became horror stories rather than solely legal stories.

Various attempts were made in the judgments to reinstate the law. The court used objective language to reassert authority as neutral arbiter:

The circumstances of and surrounding the killing of Mr Price can thus be seen to be horrendous ... Objectively the circumstances mark the killing and its accompanying incidents as being of the most gruesome kind, the murder as being in the most serious category of the crime. ${ }^{83}$

The court attempted to state the facts in neutral language, but these attempts were undermined by the reliance upon descriptive language more suited to

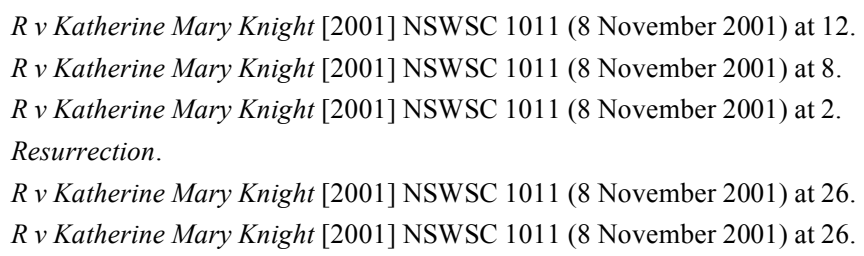


the language of horror - such as 'horrendous', 'gruesome', 'macabre' and 'grisly'. The extent to which the law was operating in an unfamiliar genre was shown by O'Keefe's misspelling of 'grisly' as 'grizzly' - a mistake quoted without correction by McClellan CJ. ${ }^{84}$

The courts also made great efforts to reinstate Price's identity, which had been undermined by Knight's decapitation, skinning and cooking of the corpse. Throughout the judgment, Price was consistently called 'Mr Price', in contrast to the practice of other homicide cases where he would have been denoted as either 'the deceased' or the 'victim'. At times, these linguistic efforts are quite awkward - for example, 'the cooking of Mr Price's head took place at a time into the early morning of 1 March $2000^{85}$ and 'the skinning, dismemberment and partial cooking of Mr Price had taken place' ${ }^{86}$ Labelling the victim 'Mr Price' throughout can be contrasted with the tendency in the judgments to call Knight either 'the prisoner' at first instance, or 'the appellant' on appeal. The judgments sought to reinstate Price's identity and erase Knight's.

The contamination of the legal system through Knight's action is portrayed starkly in the treatment of Price's body post mortem: 'So expertly was it done that, after the post mortem examination, the skin was able to be re-sown [sic] onto Mr Price's body in a way which indicated a clear and appropriate, albeit grizzly [sic], methodology. ${ }^{87}$ As a consequence of Knight's actions, the legal system played with Price's corpse as well. The contamination of the crime/legal scene reflected and reinforced her construction as monstrous. The courts were compelled to cross over borders, to examine and judge actions that undermined and challenged laws and humanity, and that were beyond the contemplation of humanity and law.

The court organised Knight's culpability as monstrous by emphasising the transgression of cherished borders with enjoyment and pleasure, for no reason or justification. According to this conception, she acted against or beyond the law with no reason. Her behaviour transgressed the law, undermining cherished boundaries between reality and fantasy, human and animal, and human and food. In the process, her actions contaminated the law, with the case reading more as horror story, the crime scene polluted. The court inscribed Knight as monstrous due to her rites of defilement through her abject behaviour, she became contaminated and polluted, an inhuman/human. The court sought to clarify and reinforce these borders through the figure of the monster, de-emphasising ambiguity, clearly placing her outside human behaviours and roles.

\footnotetext{
${ }^{84} \quad$ Knight $v R[2006]$ NSWCCA 292 (11 September 2006) at 3; $R v$ Katherine Mary Knight [2001] NSWSC 1011 (8 November 2001) at 16.

${ }_{85} \quad R v$ Katherine Mary Knight [2001] NSWSC 1011 (8 November 2001) at 20.

$86 \quad R v$ Katherine Mary Knight [2001] NSWSC 1011 (8 November 2001) at 64.

$87 \quad R v$ Katherine Mary Knight [2001] NSWSC 1011 (8 November 2001) at 16.
} 


\section{The Problem of Female Monsters}

I have argued that the model of monstrous wickedness arises when our borders and systems of order and understanding fail. Theories of the monstrous, abject, disorderly and undecidable emphasise that where we draw our boundaries, how we organise our systems of classifications, are contingent. Much of the fear associated with the monstrous is because they may compel us to question and redraw our cherished systems of order ${ }^{88}$ In law, the monstrous emerges when legal categories are exhausted and the perpetrator is characterised as being beyond the law's understanding. I would argue that legal categories are exhausted particularly early for women who kill. Feminists have noted that the subject positions available for women who kill are those of victim, mad or bad. ${ }^{89}$ Moreover, within these categories, there is a preference in criminal law to organise women who kill as victims in the agent/victim dichotomy..$^{90}$ Statistically, women are most likely to enter the criminal legal system as victims rather than as perpetrators. Crime is perceived as a predominantly masculine pastime, hence male offenders do not need to be explained. In contrast, it is exceptional for women to commit crimes, so they are deemed doubly deviant: as offending against both the state and femininity. ${ }^{91}$ When women kill, their behaviour is regarded as needing to be explained, and this is done either through a discourse of victimisation and/or one of madness..$^{92}$ Both of these subject positions ascribe limited agency due to either circumstances or irrationality. This is consistent with a legal preference to organise women as lacking agency.

A similar preference for the category of 'victim' has been noted in feminist examinations of evil. Gendered forms of evil - particularly domestic violence, sexual assault and abuse - have appropriately and effectively been the central motif of many feminist legal engagements, with some extremely important and beneficial consequences for women. Part of the success of these engagements has been through appeal to the victim subject. ${ }^{93}$ However, many feminists have recognised that the exclusive reliance upon the victim subject to make claims for rights and female empowerment has serious limitations. ${ }^{94}$ An exclusive focus on women as victims of violence does not reveal the complexity of women's lives, but only the different ways in which women experience violence. This representation of women lacks complexity and is far from liberating. It constructs a fictitious homogenous subject who is weak, disempowered, vulnerable and in need of protection. Cultural, racial, class and religious

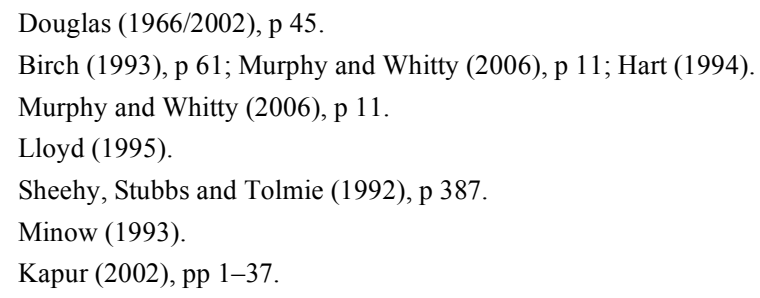


differences are all subsumed into the category of gender through women's common experience of sexual violence. ${ }^{95}$ Increasingly, feminists have recognised the need to shift away from an exclusive focus on the victim subject, analysing not just subjugation but also moments of resistance.

The disruption of the victim subject is occurring in many fields of feminism, and has been utilised to rethink and reformulate agency. The categories of victim and mad assume and assert a lack of agency. An alternative position available for women who kill is 'bad'. Allowing the possibility of female evil is essential to the recognition of women as full subjects, capable of vices and wickedness because we are capable of virtues and goodness. ${ }^{96}$ This is significant not in terms of celebrating wicked women, ${ }^{97}$ but in allowing women a full spectrum of possible behaviours that is, recognising and according women full agency, a capacity to choose wickedness as well as goodness. However, we also need to be wary of the type of conception of wickedness relied upon to organise female offenders. I argue that an attribution of wickedness does not necessarily preclude agency; rather, the admission of agency depends on which model of wickedness is applied.

As discussed above, the models of instrumental and pure evil ascribe rational choice to do wrong, either to achieve specific ends or simply to inflict suffering. These models organise perpetrators as agents capable of exercising reason and choice - albeit bad reasoning and/or choices. In contrast, the model of monstrous evil ascribes limited agency. The monstrous conception precludes rational explanation for behaviour. Monsters is evil because they are monstrous, and they are monsters because they are evil. In horror films, this drive of malevolence is depicted as beyond the control of the monster - vampires drink blood, zombies eat brains because they must. Although they are capable of action, they lack reason and choice. ${ }^{98}$ The role of monstrous evil prescribes limited agency to characters. They are inscribed as irrational malevolent creatures who want our suffering, requiring extreme responses in order to reinstate the boundaries they have challenged. Knight was represented as born bad, lacking any reason for her past or present behaviour, apart from her 'nature'.

Thus, in terms of choices of models of wickedness, the monstrous conception appears most consistent with ascribing women limited agency. Courts appear unable to understand women who kill as acting freely and rationally. Either women are victims or mad, or the legal categories are exhausted and they are monstrous. All these models stress the limited agency

95 Fuss (1989); Harris (1990); Kapur (2002), pp 1-37; Schor and Weed (1994).

96 Midgley (1984/2001), p 3.

97 Adler (1975).

98 This narrative theme has been disrupted where monsters have some choice not to be evil, but this is rare. See, for example, Angel and Spike in Buffy the Vampire Slayer. In True Blood, vampires have a choice of whether they will eat (and kill) humans, or drink synthetic blood. However, even Bill Sykes - the 'good' vampire - almost kills Sookie in Season 3 when he is starving. 
of women who kill. However, the organisation of women who kill as monstrous generates problems. I will explore the way in which gender configurations apply in the monster/victim dichotomy. The binary relations inscribed in law are not stable, coherent or consistent. I argue that the law retains its preference for ascribing limited agency to women who kill, which leads to a desire to organise victimhood as feminine and monstrosity as masculine. This generates a problem for the law illustrated in Knight: can women be monstrous, or is monstrosity masculine? I draw upon two different approaches to the question of the gendered configuration of monsters that have been expounded in cultural studies. One approach associates agency with men, and thus regards female monsters as acting like men. A second approach argues for a monstrous feminine, constructed in relation to fears about mothering and reproduction, represented in the vagina dentate. I will consider each approach in turn.

\section{Knight Acting Like a Man}

In Men, Women and Chainsaws, Carol Clover analyses the map of gender configurations of characters in traditional horror films. ${ }^{99}$ Clover explores the character of the 'final girl' and how this impacts on the primary viewing audience - young males. The final girl manages to survive attacks of the monster even as her friends die around her, and at the end of the film manages - often with extreme violence and methods - to defeat the monster. ${ }^{100}$

Given that the last character standing is a woman (although there may still be a suggestion that the monster is still alive for a sequel), Clover examines how the primary audience of young men copes. Clover accepts that audience members are capable of identifying with characters of different genders - in other words, she recognises the potential for some gender fluidity. However, the core of her analysis reflects and reinforces gender essentialism. She argues that traditional horror stories characters perform functions that are either female or male:

The functions of monster and hero are far more frequently represented by males and the function of victim far more garishly by females. The fact that female monsters and female heroes, when they do appear, are masculine in dress and behaviour (and often even name), and that male victims are shown in feminine postures at the moment of their extremity, would seem to suggest that gender inheres in the function itself - that there is something about the victim function that wants manifestation in a female, and something about the monster and hero functions that wants expression in a male. Sex, in this universe, proceeds from gender, not the other way around. A figure does not cry and cower because she is a woman; she is a woman because she cries

99 Clover (1992).

100 The rules of horror are expounded and parodied in the Scream series. 
and cowers. And a figure is not a psychokiller because he is a man; he is a man because he is a psychokiller. ${ }^{101}$

Clover argues that horror films illustrate a strict binary of victim/agent, and accordingly excludes the feminine from the active subject position. Even when monsters or heroes are women in horror films, they are acting like men. Clover supports her claims by asserting that the final girl is 'boyish' and not fully feminine in the way of her friends. ${ }^{102}$ Her gender is compromised by her apartness from other girls, her masculine interests and her inevitable sexual reluctance. ${ }^{103}$ When she kills the monster, she addresses the monster on his own terms: 'She has not just manned herself; she specifically unmans an oppressor whose masculinity was in question to begin with.' ${ }^{104}$ She literally or symbolically castrates the killer by slashing or stabbing him open.

Clover thus argues that it is a cinematic habit in horror films for the role of monster or hero to be gendered masculine. The role of victim or 'abject terror' is gendered feminine. Woman exists in the horror film (and criminal law) primarily as victim. When women die in horror films, the camera focuses lovingly on their abject terror. 'Perfect as a tearful victim, what she does best is to faint in the arms of a gorilla, or a mummy, or a werewolf, or a Frankenstein creature.' ${ }^{105}$ Clover argues that when men are victims in horror films, their deaths are usually quick, but in dying they are configured as feminine. Horror film reflects and reinforces the Freudian essentialist view that woman, by nature, is a victim. This is consistent with Freud's depiction of woman as terrifying because she is castrated - that is, already constituted as a victim. ${ }^{106}$

Clover's ideas represent a simplification of Butler's idea of performing gender. ${ }^{107}$ According to this idea, to act - whether as monster or hero - is to perform masculinity. Victimhood is the province of feminine performance. Clover reduces agency, whether in positive or negative ways, to masculinity. This essentialist gendered analysis is clearly stated by Clover: 'the helpless child is gendered feminine; the autonomous adult or subject is gendered masculine; the passage from childhood to adulthood entails a shift from feminine to masculine'. ${ }^{108}$ Not only does Clover emphasise victimhood as feminine, with its associations with passivity and being acted upon rather

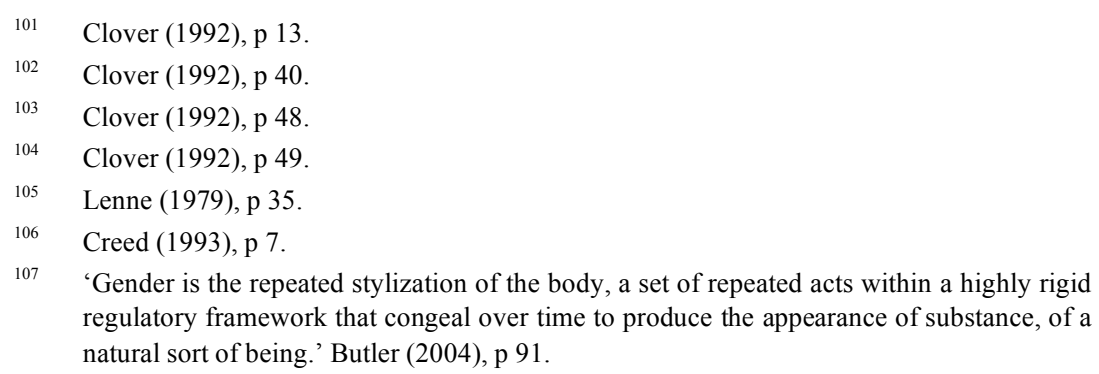

108 Clover (1992), p 50. 
than acting, but Clover's association of masculinity with monstrous action excludes women from the capacity to be wicked. Excluding women from the possibility of wickedness contributes to a denial of their agency or autonomy. If women have no capacity to be wicked, this means that they have no choice about their behaviour and are not free to choose whether to be good or bad.

Aspects of the judgment illustrate Clover's arguments. Knight's actions could be interpreted as masculine. Her actions were inspired by a fictional male counterpart in Resurrection, and in that film the unchallenged assumption by the police from the moment of the discovery of the first corpse is that the perpetrator is male. Throughout the judgment, Knight is referred to as the 'prisoner' (or on appeal as the 'appellant'). This erases her identity and her gender. The only time that her name is used in the judgment is during a quotation from the police interviews. This can be compared with the judgment at first instance consistent reference to the victim as Mr Price. Not only is this an effort to reinstate his identity, but also his gender. He has been penetrated by Knight many times with her butcher's knife. His body has been opened like a woman's. In addition, the judgment notes that the last moment of his life must have been of 'abject terror' - a position Clover considers to be 'gendered female'.

There are aspects of the judgment consistent with Clover's analysis, with a preference for stark gender essentialism reducing femininity to abject terror, with women inherently victims. In contrast, men are accorded adult subjecthood - with autonomy, choice and action. Through her actions, Knight is doubly deviant - not only does she offend against the state, but also against femininity. Following Clover's analysis, she is monstrous because she acts like a man.

\section{Knight as the Monstrous Feminine}

Barbara Creed's analysis in The Monstrous Feminine provides an alternative perspective on the place of female monsters (in law). Creed adopts a psychoanalytic approach informed by Kristeva's exploration of abjection, arguing that female monsters horrify their audience in ways that are different from male monsters. She asserts that female monsters are defined in terms of their sexuality - as with all stereotypes of the feminine. In particular, Creed argues that the monstrous feminine is constructed in relation to her mothering and reproductive functions. ${ }^{109}$ The monstrous feminine speaks to us about male fears - specifically castration. Creed argues that Freud repressed the castrating women, preferring instead to focus on the horror of women as already castrated. In contrast, Creed asserts that the castrating vagina dentata is terrifying not because she is castrated, but because she castrates. She can tear apart and reincorporate all life. This all-devouring, cannibalistic aspect is completely abject. ${ }^{110}$

$\begin{array}{ll}109 & \text { See also Ussher (2006). } \\ 110 & \text { Creed (1993). }\end{array}$ 
There are elements of the vagina dentata in Knight's case. Although not much emphasis is placed upon it in the judgment, Knight is represented as having a voracious sexual appetite. ${ }^{111}$ Kellett stated that 'on their wedding night in which she choked him by grabbing his throat because of what she perceived to be the comparative inadequacy of his sexual performance'. ${ }^{112}$ She had also threatened Price and other lovers with castration: 'If you leave me I will cut your balls out.' ${ }^{113}$ Knight appears to have had sex with Price just prior to killing him: "[S]he had a joyous day apparently filled with loving grandchildren and children, followed by enjoyable sex, with no hint of any aggression.' ${ }^{114}$ Post-coital death is a common feature of horror films. Knight appears to embody a classic position of female monster, having sex and then devouring her lover - a black widow spider.

In addition to fitting the mould of the cannibalistic, castrating woman, Knight parodied the feminine with an excessive performance of the nurturing maternal. Her use of a knife to kill - which could have Freudian interpretations of penetration - is consistent with the tendency of women to kill (usually violent) intimates with household implements, particularly knives. ${ }^{115}$ Knight used a knife, but exceeded common practice. Instead of just using a kitchen implement, the facts are clear that she used a knife from her trade and specifically as part of the scene.

Knight was defiantly feminine in her organisation of the crime scene and the rite of defilement - extravagantly parodying the role of mother and nurturer. In particular, when cooking Mr Price's body parts she took the time to prepare and peel vegetables. She exceeded her role as nurturer by leaving plates for her stepchildren with buttock steaks and cooked vegetables by the stove. This was performative as she knew that the children would not be returning to the home in the near future. She also left some buttock steaks out for a non-existent dog. This was an excessive performance or parody of the nurturing maternal - a defiantly female monster. Moreover, Knight refused to speak at trial, with silence a traditional and mythic feminine role. ${ }^{116}$

Accordingly, despite attempts in the judgment to neutralise Knight's gender, her exaggerated performance of femininity at the crime scene resulted in her characterisation as a female monster. It was this aberrant feminine behaviour that was depicted as depraved, monstrous and abject - as

111 Similar arguments have been made about Hindley: 'Although the prosecution placed considerable emphasis on Hindley's alleged sexual aggressiveness and on the crimes themselves as a violation of norms of femininity and maternity, the judge's summation avoided these discourses and focused instead on the strong incriminating evidence.' Murphy and Whitty (2006), p 12.

$112 \quad R v$ Katherine Mary Knight [2001] NSWSC 1011 (8 November 2001) at 30.

$113 \quad R v$ Katherine Mary Knight [2001] NSWSC 1011 (8 November 2001) at 50, 53.

114 R Katherine Mary Knight [2001] NSWSC 1011 (8 November 2001) at 99,

115 Mouzos (2000). In contrast, men are also likely to use hands and/or feet as lethal weapons.

116 See, for example, Creed's analysis of the sphinx as an object of narrative of the male hero. Creed (1993), p 26. 
beyond the borders of humanity. She performed an excess of femininity. The monstrous feminine exceeds the law; it is created when legal categories are exhausted due to a failure to comprehend women who kill. The monstrous feminine suspends gendered assumptions of the victim/perpetrator dichotomy and disrupts the categories themselves. It demonstrates the advantage of complex notions of violence and culpability that are unrestricted by a requirement to ascribe either victim or perpetrator status. The possibility of monsters that have themselves been victimised is a possibility within the genre of horror. ${ }^{117}$ Monsters such as Frankenstein, vampires and zombies are perpetrators of violence who have themselves been the victim of abuse, violence and contamination. Ultimately, though, horror fiction illustrates that these monsters disrupt and offend boundaries of law and society, and are abject beings who require (beseech) resolution. Knight's extravagant acts of vengeance - particularly her earlier killing of a puppy - are reminiscent of Glenn Close's fictional character in Fatal Attraction, with a complicated story of female violence. The serial killer Aileen Wuornos, labelled a monster, ${ }^{118}$ also presents a complex story of female violence. Her claims of self-defence were unsuccessful, and she refused to accede to a narrative of a 'traumatic past'. ${ }^{119}$ The failure of the legal categories creates a monstrous feminine with the potential to subvert all order. The law is unable to distinguish between her creative and destructive powers.

\section{Conclusion}

Monsters challenge and transgress cherished classifications, undermining ordered relations and identity. They excite such horror and fascination because of their potential to contaminate and pollute, to disrupt boundaries whether bodily or symbolic. Monsters demand a response, whether expulsion or exclusion, to reassert boundaries, rules and law. They emerge when categories and system of order are exhausted. This happens particularly early for women who kill - as only the limited categories of victim, mad or bad are available. I have demonstrated that we need to critically evaluate the type of model of wickedness that is relied upon to construct culpability. Knight's construction as monstrous appears to be consistent with the legal system's tendency to organise female offenders as lacking agency - she acted due to her 'nature' rather than through choice. However, monsters are in an active position, disrupting the association of women with victimhood and passivity, reaffirming and reflecting the monstrosity of Knight.

\footnotetext{
117 Zizek described Romero's Night of the Living Dead as a film 'where the "undead" are not portrayed as embodiments of pure evil, of a simple drive to kill or revenge, but as sufferers, pursuing their victims with an awkward persistence, coloured by a kind of infinite sadness ... a melancholic sufferer longing for salvation.' Zizek (1992).

118 Monster (2003). A more complex story was presented in the documentary Aileen: Life and Death of a Serial Killer (2003).

119 Hart (1994), p 152.
} 
This raises questions about the place of the monstrous (feminine) in criminal law. Should we create a category of the monstrous victim, allowing multiple subjectivities, with Knight occupying the position of both victim and perpetrator? Or should the model of monstrous wickedness be removed from the repertoire of the criminal law? Monsters demand extreme responses, and contaminate the criminal law. Reliance upon the monstrous conception of evil suggests that we have drawn the borders of humanity in the wrong places. The model of monstrous wickedness assists in evading the legal (and moral) duty to judge humans as humans. Monstrous wickedness is overly simplistic and does not adequately grapple with responsibility and agency. It allows us to turn away from the violent experiences which shaped Knight. We use the monstrous conception of evil to hide not from the monster but from ourselves. If we rethink the human and allow the freedom to choose any possibility, then we admit agency (for women) to choose evil. If we cannot choose between good and evil then we are moral automatons.

\section{Acknowledgements}

The author is grateful for the assistance from the New South Wales Law Society Public Purpose Fund.

\section{References}

\section{Primary Legal Sources}

Knight $v R$ [2006] NSWCCA 292 (11 September 2006).

$R v$ Katherine Mary Knight [2001] NSWSC 1011 (8 November 2001).

\section{Secondary Sources}

Freda Adler (1975) Sisters in Crime, McGraw Hill.

Richard Bernstein (2002), Radical Evil: A Philosophical Interrogation, Polity Press.

Helen Birch (ed) (1993) Moving Targets: Women, Murder and Representation, Virago.

Judith Butler (2004) 'Bodily Inscriptions, Performative Subversions', in Sara Salih and Judith Butler (eds), The Judith Butler Reader, Wiley-Blackwell.

Claudia Card (2002) The Atrocity Paradigm: A Theory of Evil, Oxford University Press.

Carol Clover (1992) Men, Women, and Chain Saws: Gender in the Modern Horror Film, Princeton University Press.

Phillip Cole (2006) The Myth of Evil, Praeger.

Jeff Collins and Bill Mayblin (1996) Derrida for Beginners, Icon.

Barbara Creed (1993) The Monstrous Feminine: Film, Feminism, Psychoanalysis, Routledge.

Margaret Davies (2008) Asking the Law Question, Thomson Law Book Company.

Andrew Delbanco (1995) The Death of Satan, Farrar, Straus \& Giroux.

Mary Douglas (1966/2002) Purity and Danger: An Analysis of the Concepts of Pollution and Taboo, Routledge \& Kegan Paul.

Patricia Easteal (1993) Killing the Beloved, Australian Institute of Criminology. 
Jacob Finkelstein (1973) 'The Goring Ox: Some Historical Perspectives on Deodands, Forfeitures, Wrongful Death and the Western Notion of Sovereignty' 46(2) Temple Law Quarterly 169.

Francois Flahault (2003) Malice, Liz Heron trans, Verson.

George Fletcher (1978) Rethinking Criminal Law, Little, Brown \& Co.

Michel Foucault (1975) I, Pierre Riviere, Having Slaughtered My Mother, My Sister and My Brother ... A Case of Parricide in the 19th Century, University of Nebraska Press.

Sigmund Freud (1930/1975) Civilization and its Discontents, Joan Riviere trans, Hogarth Press. Diana Fuss (1989) Essentially Speaking: Feminism, Nature and Difference, Routledge.

David Garland (1990) Punishment and Modern Society, University of Chicago Press.

Angela Harris (1990) 'Race and Essentialism in Feminist Legal Theory' 42 Stanford Law Review 581.

Lynda Hart (1994) Fatal Women: Lesbian Sexuality and the Mark of Aggression, Routledge.

Daniel Haybron (2002) 'Introduction: Evil as a Philosophical Concern', in Daniel Haybron (ed), Earth's Abominations: Philosophical Studies of Evil, Rodopi.

Thomas Hobbes (1651/1991) Leviathan, Cambridge University Press.

Ratna Kapur (2002) 'The Tragedy of Victimisation Rhetoric: Resurrecting the "Native" Subject in International/Post-Colonial Feminist Legal Politics' 15 Harvard Human Rights Journal 1.

J Kaye (1967) 'The Early History of Murder and Manslaughter: Part I' 83 Law Quarterly Review 365.

Julia Kristeva (1982) Powers of Horror: An Essay on Abjection, Columbia University Press.

Peter Lalor (2002) Blood Stain: The True Story of Katherine Knight to Mother and Abattoir Worker who Became Australia's Worst Female Killer, Allen \& Unwin.

Sandra Lee (2002) Beyond Bad: The Life and Crimes of Katherine Knight, Australia's Hannibal, Bantam.

Gerard Lenne (1979) 'Monster and Victim: Women in Horror Film', in Patricia Erens (ed), Sexual Stratagems: The World of Women in Film, Horizon.

Ann Lloyd (1995) Doubly Deviant, Doubly Damned: Society's Treatment of Violent Women, Penguin.

Rohan Lulham and Jacqueline Fitzgerald (2008) 'Trends in Bail and Sentencing Outcomes in New South Wales Criminal Courts: 1993-2007', Crime and Justice Bulletin, NSW Bureau of Crime Statistics.

Mary Midgley (1984/2001) Wickedness: A Philosophical Essay, Routledge \& Kegan Paul.

Martha Minow (1993) ‘Surviving Victim Talk’ 40 University of California Law Review 1411.

Adam Morton (2004) On Evil, Routledge.

Jenny Mouzos (2000) Homicidal Encounters: A Study of Homicide in Australia 1989-1999, Australian Institute of Criminology.

Therese Murphy and Noel Whitty (2006) 'The Question of Evil and Feminist Legal Scholarship' 14 Feminist Legal Studies 1.

Ngaire Naffine (1997) Feminism and Criminology, Temple University Press.

Susan Neiman (2002) Evil in Modern Thought, Princeton University Press.

Martha Nussbaum (1999) 'Secret Sewers of Vice: Disgust, Bodies and the Law', in Susan Bandes (ed), The Passions of Law, New York Univeristy Press.

Wendy Pearson (2003) "I, the Undying": The Vampire of Subjectivity and the Aboriginal "I", in Annalise Oboe (ed), Mongrel Signatures: Reflections on the work of Mudrooroo, Rodopi.

Peter Rush (1997) Criminal Law, Butterworths.

Naomi Schor and Elizabeth Weed (eds) (1994) The Essential Difference, Indiana University Press. 
Elizabeth Sheehy, Julie Stubbs and Julia Tolmie (1992) 'Defending Battered Women on Trial:

The Battered Woman Syndrome and Its Limitations' Criminal Law Journal 369.

Robert Louis Stevenson (1886/1979) The Strange Case of Dr Jekyll and Mr Hyde, Penguin.

Jane Ussher (2006) Managing the Monstrous Feminine: Regulating the Reproductive Body, Routledge.

James Boyd White (1978) 'Making Sense of Criminal Law' 50 University of Colorado Law Review 1.

Alison Young (1996) Imagining Crime: Textual Outlaws and Criminal Conversations, Sage.

Alison Young (2000) 'Aesthetic Vertigo and the Jurisprudence of Disgust' 11 Law and Critique 241.

Alison Young (2009) The Scene of Violence: Cinema, Crime, Affect, Routledge.

Slavoj Zizek (1992) Looking Awry: An Introduction to Jacques Lacan Through Popular Culture, MIT Press.

Slavoj Zizek (1999) 'Fantasy as a Political Category: A Lacanian Approach', in Elizabeth Wright and Edmond Wright (eds), The Zizek Reader, Blackwell. 